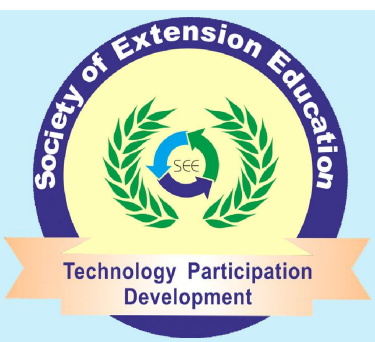

Research Article

\section{Indian Research Journal of Extension Education}

ISSN: 0972-2181 (Print), 0976-1071 (Online)

NAAS Rating : 5.22

Journal homepage: seea.org.in

https://doi.org/10.54986/irjee/2022/jan_mar/110-113

\title{
Performance of Entrepreneurs in North Eastern Region
}

\author{
Pubali Saikia ${ }^{1}$ \\ 1. Asstt. Prof., Vidya Bharati College, Kamrup (Assam) \\ Corresponding author e-mail : pubalisaikia1983@gmail.com
}

Paper Received on September 28, 2021, Accepted on November 20, 2021 and Published Online on January 01,2022

\begin{abstract}
Entrepreneurship development through micro enterprise is an economic venture by which a large number of people can be changed within a short period of time especially from the point of view of employment generation. It provides tremendous opportunities for an entrepreneur to start a new creation. It helps to change the life of an entrepreneurs into a new direction. For changing the life of an entrepreneur, motivation is very essential, because without motivation no one can choose entrepreneurships as a profession. As we know it very well, that motivation is the ultimate key of starting a new venture in any trade. So it is very much important to motivate a person to understand his or her inner qualities to start a new profession for economic development. This study was conducted in the state of Assam. The nature of the study was both Exploratory and Descriptive. For selecting the representative sample for the study, simple random sampling method was adopted for selection of the districts. CRD analysis highlights the significance difference among all aspects of empowerment.
\end{abstract}

Keywords: Performance; Entrepreneur.

$\mathbf{E}_{\text {ntrepreneurship is measured as an engine of }}$ development for an economy. It is the central force of economic activity and prime mover of economic development. Moreover, it is vital for businesses' and economies' growth. It has a creativity that promotes the foundation of new organizations. Entrepreneurship happens to be one of the best ways towards self sufficiency and poverty alleviation for women in a country where employment is not guaranteed. Moreover, involvement of women in entrepreneurial activities would ensure effective utilization of labour, generation of income and hence improvement in quality of life. Economic empowerment of women by entrepreneurial activities led to the empowerment of women in many things such as socio-economic opportunity, property rights, political representation, social equality, personal right, family development, community development and at last the nation development. The role played by an entrepreneur is of vital importance in developing country like India, where there are ample opportunities for using innovations to exploit the available resources, particularly in all fields that include weaving and food processing and preservation sectors also. There is a large scope for entrepreneurial involvement as it provides employment, generates income, wealth and act as a key force for economic growth of a region. So it is necessary to encourage women to enter in the gainful profession of entrepreneurship to develop socially, economically and technologically to enable them to stand in society on their own with confidence. Alam et al. (2012) 
revealed that 30.90 per cent of women entrepreneurs belonged to 31-40 years age group, 33.00 per cent were diploma holders, 1.50 per cent had education up to master degree level and 75.30 per cent were married. Jha (2012) reported from his study on "Development of Women Entrepreneurship - Challenges and Opportunities - A Case Study of Bihar" that 52.50 per cent of respondents were graduates, followed by under graduate $(27.50 \%)$. The study also revealed that 08.0 per cent of respondents had education up to post graduate level and only 4.00 per cent of respondents had completed different professional courses like MBA or Engineering. Pharm and Sritharan (2013) reported that 46.67 per cent of the respondents had educational exposure up to higher secondary level, 20.00 per cent of them were graduates, 17.78 per cent had secondary level education, 10.00 per cent had primary education and rest of them were illiterates. This study also revealed that majority of women entrepreneurs $(69.00 \%)$ were married and 31.00 per cent were unmarried.

Palaniappan et al. (2012) highlighted that lack of strong leadership, systematic planning and working followed by health problem, non- awareness of government schemes, non repayment of loans by the family members, lack of education and proper training were main problems faced by the women entrepreneurs in Tamil Nadu. Ram et al. (2013) mentioned that majority $(66.60 \%)$ of women entrepreneurs in Ima market was middle aged group of 38-62 years, 21.30 per cent had education up to college level and 23.30 per cent were illiterates, 47.30 per cent belonged to medium size family with 4- 6 members and 70.00 per cent of women entrepreneurs in were married. Angaine and Waari (2014) conducted a study on "Factors influencing loan repayment in micro-finance institutions in Kenya" and highlighted that there were various factors like inherent characteristics of borrowers and businesses condition, the characteristics of the lending institution, suitability of the loan product to the borrower, systematic risk, external factors such as the economic, political and business environment influenced borrower for nonrepayment of loans.

The increasing presence of women in the business field as entrepreneurs or business owners in the last decades has changed the demographic characteristics of entrepreneurs. Moreover, North East is seen as a region where more women are involved in income generating activity than women of the other parts of the country. Different research studies have shown that more number of women are involved in micro enterprise than small and medium enterprises. Therefore, an effort has been made to study Performance of Entrepreneurs in North Eastern Region with following objectives:

1. To study the background characteristics of women entrepreneurs.

2. To evaluate the impact of micro enterprise on selected aspects of empowerment.

\section{METHODOLOGY}

This study was conducted in three districts namely Kamrup district, Lakhimpur district and Jorhat district of Assam. The criteria for selection of women entrepreneurs was decided as entrepreneurs must have completed at least three years and employed at least two or more regular employees of either sex. Then, a total of 120 numbers of women entrepreneurs engaged in tailoring unit were selected as a sample.

Impact of micro enterprise on empowerment of women entrepreneurs was assessed in four dimensions namely economic, social, familial and legal factors through development of women empowerment indices. For finding out the difference between before and after, data was collected from entrepreneurs after starting the enterprise through personal interview method which was supplemented by records and documents. The collected data was coded, tabulated and analyzed in accordance with the objectives of the study. The statistical techniques used for analysis of data wereMean Score, Paired ' $t$ ' test, Empowerment Indices and Critical Randomized Design (CRD Analysis).

\section{RESULTS AND DISCUSSION}

For easy interpretation the results and discussion were grouped in the following sub-heads.

Background characteristics: The data presented in the Table 1 revealed that a large majority $(75.00 \%)$ of the respondents engaged in the area of tailoring were from lower middle age group (31-50 years), only a small percentage $(9.17 \%)$ was from upper middle age group might be due to secure their families economically that inspired them to enter in this area as a livelihood option.

The data on distribution of respondents according to their caste is presented in the Table 1 reflected that a sizeable per cent of the respondents $(30.83 \%)$ engaged 
in tailoring unit were from schedule tribe followed by general caste $(26.67 \%)$.

The findings reflected that women in the study area had varied level of educational qualification. With education women entrepreneurs learn some business tips thus decided to enter in the area of enterprise development as a source of business for their livelihood.

The data with regard to marital status is presented in the Table 1 highlighted that a large majority of the respondents $(87.50 \%)$ were married. Only a small percentage $(0.83 \%)$ were widower in the area of tailoring unit might be due the fact that being married the financial liability of the respondents increases such as education of the children, health security of family, so they are inclined to set up a weaving unit as a source of assured income.

The findings reflected that nuclear family is replacing the joint and extended family in our society which might be due to the disintegration of joint and extended family systems in the present day society in rural areas.

The data with regard to the size of family is presented in the Table 1 showed that more than half of the respondents were from small family.

The findings also indicated that young generation mostly preferred small families as it provides golden opportunity for everyone to utilize their spare time efficiently in any areas of enterprises.

The data on main occupation of family is presented in Table 1 indicated that business was the main occupation for 61.67 per cent of respondents in this area.

Majority of the respondents belonged to the business family which was a great influencing factor for the respondents to take up entrepreneurship as a profession due to the prevailing of business to establish their own identity as well as to reach success in this area .

Impact of micro enterprise on empowerment of women entrepreneurs: The data presented in the Table 2 revealed that there is improvement in all aspects of the entrepreneurs in the area of tailoring except the legal aspect which was reflected through the mean difference in the obtained score before taking up enterprise and after becoming an entrepreneur.

The probable reason of change between two stages in this area might be due to interaction with successful
Table 1. Distribution of respondents according to background characteristics $(\mathrm{N}=120)$

\begin{tabular}{llll}
\hline Characteristics & Category & \multicolumn{2}{c}{ Weaving } \\
& & No. & $\%$ \\
\hline Age & Young & 19 & 15.83 \\
& Lower middle & 90 & 75.00 \\
Caste & Upper middle & 11 & 9.17 \\
& ST & 37 & 30.83 \\
& SC & 24 & 20.00 \\
& OBC & 27 & 22.50 \\
Qualification & General & 32 & 26.67 \\
& Upto class X & 23 & 19.16 \\
& H.S.L.C. Pass & 48 & 40.00 \\
& H.S.Pass & 22 & 20.00 \\
& Graduate & 18 & 15.00 \\
& Post Graduate & 5 & 4.17 \\
& Certificate course & 4 & 3.33 \\
Marital Status & Unmarried & 14 & 11.67 \\
& Married & 105 & 87.50 \\
& Widow & 1 & 0.83
\end{tabular}

Family structure

Family type

$\begin{array}{lll}\text { Nuclear } & 73 \quad 60.83\end{array}$

Joint $\quad 30 \quad 25.00$

Extended $\quad 17 \quad 14.17$

$\begin{array}{llll}\text { Family size } \quad \text { Small (<4 members) } & 79 \quad 65.87\end{array}$

Medium (5-7 members) $\quad 29 \quad 24.17$

Large ( 8 and above) $\quad 12 \quad 10.00$

$\begin{array}{lll}\text { Family occupation Service } & 8 & 6.67\end{array}$

$\begin{array}{lll}\text { Business } & 74 \quad 61.67\end{array}$

Farming $\quad 38 \quad 31.66$

entrepreneurs, active participation in expo/mela which inspired them to change their perspective regarding different aspects of empowerment.

Table 2. Impact of micro enterprise on empowerment of women entrepreneurs

\begin{tabular}{llcc}
\hline $\begin{array}{l}\text { Aspects of } \\
\text { empowerment }\end{array}$ & Stages & $\begin{array}{c}\text { Weaving } \\
\text { Mean index value }\end{array}$ & t-value \\
\hline Economic & Before & 18.72 & $12.43^{* *}$ \\
& After & 25.30 & \\
Social & Before & 16.04 & $9.78^{* *}$ \\
& After & 34.70 & \\
Familial & Before & 27.10 & $13.97^{* *}$ \\
& After & 36.31 & \\
Legal & Before & 30.24 & $1.25^{\mathrm{NS}}$ \\
& After & 32.59 & \\
\hline
\end{tabular}

** Significance at 0.01 probability level

The data presented in the Table 2 reflected that 
changes were taken place and highly significant in the different aspects of empowerment such as economic, social and familial. But it was not highly significant in the legal aspect might be due to the fact that women entrepreneurs started their enterprises at micro level and still continuing as micro enterprise where much of the legal procedures are not involved. Further, majority of the respondents started their business with sole proprietorship, so need of legal adviser was almost nil, that might be the reason though there was a change but not very high. Hence, government should organize awareness camp, training programme covering the aspects of legal issues related to enterprise development.

Table 3. Ranking of empowerment aspects on women entrepreneurs

\begin{tabular}{lll}
\hline Aspects of & \multicolumn{2}{l}{ Tailoring nit } \\
empowerment & MS & Rank \\
\hline Economic & 2.20 & I \\
Social & 1.10 & II \\
Familial & 0.80 & III \\
Legal & 0.31 & IV \\
\hline
\end{tabular}

It is observed from Table 3 that among all the empowerment aspects, economic aspect ranked I followed by social aspect and familial aspect. On the other hand, legal aspect got the lower rank with a lower mean score. Aspect ranked low be taken into consideration during the time of training intervention for improving knowledge of women entrepreneurs in the domain of legal rights for their safety. It is also essential for women entrepreneurs to develop their awareness level regarding legal rights so that they can protect themselves from any kind of exploitation. It is also observed from the findings that women entrepreneurs of the study area were not concerned about legal issues. So it is very essential to motivate them for updating their knowledge on legal matter.

\section{CONCLUSION}

The findings further highlighted that there is improvement in all aspects of the entrepreneurs in the area of tailoring unit except the legal aspect. The maximum influencing factors in weaving sector were involvement in household decisions, opening of own account and contribution in food followed by control over income and purchase of household property. So the government must put forward a pressure to promotional agencies to provide financial assistance in a limited time frame for their successful growth. Hence, promotional and government agencies should launch awareness and publicity campaigns about different government schemes or programmes available for women entrepreneurs. Women entrepreneurs should be encouraged to became member of any organization such as SHG to get more facilities to run their enterprises in right direction. It is the need of the hour to help women to scale new heights in their entrepreneurial journey. The right kind of assistance from family, society and Government can make these women entrepreneurs a part of the mainstream of national economy.

\section{REFERENCES}

Alam, S.S.; Senik, Z.C. and Jani, F.M. (2012). An explanatory study of women entrepreneurs in Malaysia: motivation and problems. J. Mngt. Res., 4 (4) : 282-297.

Jha, N.K. (2012). Development of Women Entrepreneurship - Challenges and Opportunities- A Case Study of Bihar. Ninth AIMS Intern. Conf. Mngt., pp. 214-221.

Pharm, A.D. and Sritharan, R. (2013). Problems being faced by women entrepreneurs in rural areas. Intern. J. Engg. Sci. (IJES) $2(3): 52-55$.

Palaniappan, G.; Ramanigopal, C.S. and Mani, A. (2012). A study on problem and prospects of women entrepreneurs with special reference to Erode district. Intern. J. Physic. Soc. Sci. 2 (3): 219-230.

Ram, D.; Singh, M.K.; Chaudhary, K.P. and Jayarani, L. (2013). Entrepreneurship behaviour of women entrepreneurs in Imphal of Manipur. Indian Res. J. Extn. Edn., 13 (2): 31-35

Angaine, F. and Waari, D.N. (2014). Factors influencing loan repayment in Micro-Finance Institutions in Kenya. IOSR J. Bus. Mngt., $16(9):$ 66-72. 